\title{
Pornography, Panopticism and the Criminal Justice and Immigration Act 2008*
}

Julian Petley, Professor of Film and Television, School of Arts, Gaskell Building, Brunel University Uxbridge, UB8 3PH, UK. Email: julian.petley@brunel.ac.uk

\begin{abstract}
In May 2008, the Criminal Justice and Immigration Act was passed in the United Kingdom. Among other things, this made it an offence even to possess what it describes as an 'extreme pornographic image'. This paper analyses the particular factors which gave rise to this measure, support for it amongst the police and politicians, and the problems which are likely to arise from attempts to enforce it. In particular, the paper argues that the measure is so ill-conceived that it is likely to criminalise the possession of a far wider range of images than was originally intended. More generally, the paper examines the Act in the context of (a) the increasing tendency on the part of governments both democratic and nondemocratic to attempt to regulate the Internet and its users; (b) the development of the 'surveillance society'; and (c) New Labour's marked tendency to legislate for private and personal realms traditionally regarded as out-of-bounds in a democratic polity. The paper concludes that the Criminal Justice and Immigration Act is a disturbing symptom of the development of the United Kingdom as not simply a surveillance society but also a postsocial democratic state.
\end{abstract}


It doesn't seem that long ago that the new communications technologies, and especially the Internet, were being celebrated as the greatest boost to freedom of expression since Johannes Gutenberg invented the printing press in the mid-15th century. As Howard Rheingold put it in 1993 in the first edition of The Virtual Community: 'Information can take so many alternative routes when one of the nodes of the network is removed that the Net is almost immortally flexible. It is this flexibility that CMC telecom pioneer John Gilmore referred to when he said, "The Net interprets censorship as damage and routes around it"' $(1993,7)$. However, by the time the new edition of the book was published in 2000 , things had changed considerably. Note, for instance, how Manuel Castells in his helpful encapsulation of the libertarian vision of the Internet is careful to use the past tense throughout:

Created as a medium for freedom, in the first years of its worldwide existence the Internet seemed to foreshadow a new age of liberty. Governments could do little to control communication flows able to circumvent geography, and thus political boundaries. Free speech could diffuse throughout the planet, without depending on mass media, as many could interact with many in an unfettered manner. Intellectual property (in music, in publications, in ideas, in technology, in software) had to be shared since it could hardly be enclosed once these creations were placed on the Net. Privacy was protected by the anonymity of communication on the Internet, and by the difficulty of tracing back the sources and identify the content of messages transmitted using Internet protocols. $(2001,169)$

Just how outdated is such a view was clearly illustrated when the Culture Secretary Andy Burnham declared on 27 December 2008, in an interview with the Telegraph, that 'If you look back at the people who created the Internet they talked very deliberately about it being a space that Governments couldn't reach. I think we are having to revisit that stuff seriously now ... There is content that should just not be available to be viewed. That is my view. Absolutely categorical'.

Of course, it was precisely the global nature of the information flows facilitated by the Internet which caused the greatest consternation around the world amongst those used to keeping a tight grip on the media in their own countries. Authoritarian regimes were hardly likely to welcome an influx of democratic ideas, and many democratic ones fretted about 
alien porn and, post-9/11, terrorist propaganda. Of course, governments could shut down websites of which they disapproved if they were operating within their own jurisdictions, but these could quite easily move elsewhere and carry on as before. In particular, they could migrate to a server based in the United States, where the Internet enjoys the constitutional protection of free speech guaranteed by the First Amendment. Almost inevitably this has been challenged there, but no amount of scare stories about the Internet being dominated by child porn and fascist hate sites have managed to deny to the Internet the freedom enjoyed by other American media. Thus the 1995 Communications Decency Act, which made it illegal to distribute via the Internet 'indecent' images or other forms of communication 'in a manner available to a person under 18 years of age', was ruled unconstitutional by a US federal court in Pennsylvania on 12 June 1996, which declared: 'Just as the strength of the Internet is chaos, so the strength of our liberty depends upon the chaos and cacophony of the unfettered speech the First Amendment protects' (quoted in ibid.: 170). The court's judgement was upheld by the Supreme Court on 26 June 1997. Similarly, the 1998 Child On-Line Protection Act, which criminalised material deemed 'harmful to minors' by 'contemporary community standards', was struck down in June 2000 by the US Court of Appeals in Philadelphia.

Given that different countries would find it quite impossible to agree on what material is and is not acceptable online, even those democratic governments which would like to be able to control the Internet directly have, for the most part, realised that this is a vain hope. Instead, they have resorted to more indirect means - in particular pressuring intermediaries to engage in what are in effect various forms of self-censorship. As Jack Goldsmith and Tim Wu point out:

Internet Service Providers are the obvious first target for a strategy of intermediary control. It can be great fun to talk about the Internet as a formless cyberspace. But ... underneath it all is an ugly physical transport infrastructure: copper wires, fibre-optic cables, and the specialised routers and switches that direct information from place to place. The physical network is by necessity a local asset, owned by phone companies, cable companies, and other service providers who are already some of the most regulated companies on earth. This makes ISPs the most important and most obvious gatekeepers to the Internet. Governments can achieve a large degree 
of control by focusing on the most important ISPs that service the majority of Internet users. $(2008,73)$

Thus, for example, in Britain, ISPs are warned that once they have been informed by the industry's own self-regulatory body, the Internet Watch Foundation (IWF), that they are hosting material deemed illegal, they will be treated as publishers of that material and will be liable to prosecution if they do not remove it. (For further details of the genesis and activities of the IWF, see Akdeniz et al. 2000 and Craig and Petley 2001). Nor is such behaviour limited to censorship-inclined governments. As Nart Villeneuve has pointed out in some detail $(2007,74-6)$, when ISPs have pressured by powerful corporate interests to take down material which they claim violates defamation or copyright law, for example, their default position has been to comply rather than resist.

Another tactic is the surveillance of Internet users to ascertain whether they are accessing content which is illegal in the country in which they are based. Unable to control the global flow of information across the Internet, governments of certain democratic states are seeking instead to control its users by implanting them with the fear that if they visit websites containing material which their own government has deemed illegal, their online activity will be tracked and they will be liable to prosecution - under legislation banning hate speech or certain kinds of pornography, for example. Thus, the Internet user in such countries finds themselves in the same position as a prisoner in Jeremy Bentham's famous Panopticon, who, never sure when they are actually being watched, behaves all the time as if under surveillance, and so, as Foucault puts it, 'assumes responsibility for the constraints of power' and 'becomes the principle of his own subjection' (1977, 202-3). (For further discussion of the relevance of 'panopticism' to this issue, see Lyon 2006, 2007) Indeed, it is interesting to note just how overt threats of surveillance have actually become. Thus, for example, discussing a successful prosecution of a man arrested for using a forum containing child abuse images, Jim Gamble, Chief Executive of the Child Exploitation and Online Protection Centre (CEOP), stated: 'There is a simple message to those individuals ... who think they can go to this website - or indeed any other space on the Internet - and discuss their sexual interest in children and share images. You leave a digital footprint. We will track you down and hold you to account' (2008). Similarly, in a response to the government's consultation on the possession of 'extreme pornography' (see below), Detective Inspector 
lan Winton of the Nottinghamshire police argued that any change in the law should be accompanied by a widespread publicity campaign which will 'inhibit people from "surfing" the Internet for pornography and accessing it'.

But as such surveillance activity is liable to raise the spectre of Big Brother and to encourage comparisons with China (where currently some 50 cyber-dissidents are languishing in gaol), it has to be seen to be directed only at those universally regarded as beyond the pale, such as paedophiles or terrorists. Thus, neatly killing two birds with one stone, an article in The Times, 17 October 2008, headed 'Dangerous and depraved: where two worlds collide' stated that: 'For some, the Internet is merely a hiding place - a web of secret corridors where all manner of shameful deeds unfold. But the police never expected that it might become a strategic platform where two groups of society's outcasts, terrorists and child sex abusers, could meet to exchange operational secrets'. However, since the article singularly fails to prove the existence of any organised link, it is difficult to regard it as anything other than kite flying by the Internet's would-be censors. Moreover, it also helps to reinforce the association between the Internet and criminality which, in the United Kingdom in particular, has been such a long-standing feature of so much official and journalistic discourse about the new media and which, inevitably, has helped to lend a veneer of legitimacy to the official surveillance of Internet users.

In the United Kingdom, this has now been extended to those accessing what the government has deemed to be the 'wrong' kind of pornography - not only online but in the 'old' media as well. The story of how this particular measure came about, and analysis of what it actually entails, demonstrate how, even in democratic states, governments can and do attempt to police the Internet and its users. In Britain, this measure makes it abundantly clear that the government regards it as quite proper that agencies of the state be permitted to carry out surveillance of Internet users who are accessing material which is perfectly legal in most other democratic states, where possession of which is regarded as a purely private, personal matter.

In May 2008, the Criminal Justice and Immigration Act was passed. This made it an offence even to possess, let alone to distribute, an 'extreme pornographic image'. The Act defines an image as pornographic if 'it is of such a nature that it must reasonably be assumed to have been produced solely or principally for the purpose of sexual arousal' and as extreme if 
it is 'grossly offensive, disgusting or otherwise of an obscene character' and 'if it portrays, in an explicit and realistic way, any of the following':

a) an act which threatens a person's life;

b) an act which results, or is likely to result, in serious injury to a person's anus, breasts or genitals;

c) an act which involves sexual interference with a human corpse; or

d) a person performing an act of intercourse or oral sex with an animal (whether dead or alive);

e) and a reasonable person looking at the image would think that any such person or animal was real.

This remarkably draconian piece of legislation has its origins in two factors. First, thanks to the Internet, British subjects are now able to access material which the Obscene Publications Act would make it extremely difficult to distribute by other means. Second, the Act has not proved as effective as the censorious would like it to have been. For the purposes of the Act, an article is deemed obscene 'if its effect ... is, taken as a whole, such as to tend to deprave and corrupt persons who are likely, in all circumstances, to read, see or hear the matter contained or embodied in it'. Thus, to be obscene, an article must be more than simply sexually explicit and must have considerably more serious effects than merely shocking or disgusting certain people. These effects have to be considered in respect of those likely to seek it out as opposed to the 'average' or 'reasonable' person, or those deemed 'vulnerable'. Works have to be judged by their 'dominant effect', that is, taken as a whole and not simply on the basis of their more lurid passages, and the Act also contains a 'public good' defence, by which those accused of publishing obscene material can argue that publication is in the interests of science, literature, art or learning. And although the Act makes no overt reference to current standards of acceptability in the area of explicit imagery, one of the great virtues of the 'deprave and corrupt' test is that it does, inevitably, move with the times in this respect. As Geoffrey Robertson and Andrew Nicol put it in Media Law, in an obscenity trial, 'the collective experience of 12 arbitrarily chosen people is assumed to provide a degree of familiarity with popular reading trends, with what is deemed acceptable on television and at cinemas and on the Internet and with the degree of explicitness that can be found in publications on sale at local newsagents' $(2008,206)$. The 
combined effect of all of the above factors makes it quite difficult to mount a successful prosecution for obscenity (if the defendant chooses to present a defence, that is), and as a result, the censorious have created various means of circumventing it. Thus, the Video Recordings Act 1984 made it illegal to distribute any video which had not been certified by the British Board of Film Classification (BBFC), thus giving the Board's video (now DVD) certificates statutory force and so introducing state video censorship to the United Kingdom. Meanwhile, the Protection of Children Act 1978, as subsequently amended by other legislation, makes it an imprisonable offence to take, permit to be taken, make, possess, show, distribute or advertise indecent images of children (here defined as being apparently under 18) in the United Kingdom. 'Images' are taken to include drawings, as well as data stored on a computer disc or by other electronic means which is capable of conversion into an indecent image.

When explaining why the government saw the need for the porn clauses in the Criminal Justice and Immigration Act, in a Lords debate on the Bill on 30 April 2008, the Parliamentary Under-Secretary of State at the Ministry of Justice, Lord Hunt clearly echoed a number of the points made by Castells above:

This legislation has been proposed because the controls in the Obscene Publications Act are much more easily evaded these days by the use of modern technology, namely the Internet, which makes it much easier to use and distribute and therefore easier to possess. As most such extreme material is hosted abroad, controls on publication and distribution are no longer sufficient. (Col. 269)

Obviously, as noted earlier, the new communications media do indeed pose a challenge to all national systems of media regulation, but they pose a particularly acute one to the British authorities, habituated as they are in matters pertaining to sexual imagery to exercising a degree of control which citizens of many other democracies would regard as excessive and eccentric. However, even the British government realises that its standards are so out of line with those of other countries (although it would doubtless put this the other way round) that arriving at any kind of transnational standards of acceptability is a complete impossibility. However, rather than sensibly leaving well alone, they have decided that, as 
they cannot criminalise the distribution of material emanating from abroad of which they disapprove, they will simply criminalise its possession instead.

This alone constitutes a considerable abridgement of individual liberty which may well fall foul of the European Convention on Human Rights. Indeed, in its pre-legislative scrutiny of the Bill, the Joint Committee on Human Rights noted that the government had already indicated that it felt that the seriousness of the proposed offences justified interference with Articles 8 and 10 of the European Convention on Human Rights, which concern, respectively, an individual's right to private life and their right freely to receive and impart information (including information which is offensive or unpalatable). However, the Committee was concerned whether 'the definition of the new offence is sufficiently precise and foreseeable to satisfy the requirement' that interferences with these rights must be in accordance with the law $(2008,15)$. In particular, it wondered whether an individual user of pornography would be able to know whether their possession of a particular image would constitute a criminal offence, and noted that 'an assessment of whether an image is or is not "extreme" is inherently subjective' (ibid., 16).

However, highly subjective, not to say deeply moralistic, factors lie at the very heart of the Act's definitions of 'extreme pornography', and have played a major role in every stage of its gestation. Thus, in the consultation document which sparked off the whole process in August 2005, the material which the government wished to make it illegal to possess was described variously as 'abhorrent' (Home Office 2005a, i), 'degrading' (ibid., 10) and 'repugnant' (ibid., 11). And, announcing the consultation, Home Office Minister Paul Goggins, stated that: 'This is material which is extremely offensive to the vast majority of people, and it should have no place in our society' (Home Office 2005b).

Indeed, anyone responding critically to the consultation would have rapidly come to the conclusion that the government's mind was firmly made up on this matter and that the whole consultation exercise was a complete sham. And when in August 2006 the Home Office issued a press release announcing that it was indeed going to take action against 'extreme pornography', Home Office Minister Vernon Coaker was at pains to point out that it was doing so because 'such material has no place in our society' and because it wished to send out 'a strong message - that it is totally unacceptable and those who access it will be held to account' (Home Office 2006). 
Entirely unsurprisingly, then, vague and loaded words such as 'grossly offensive' and 'disgusting' have found their way into the Act itself, even though subjective language such as this should have no place in legislation. Aware that it had produced not a shred of proof of the negative effects of any kind of pornography, the government did, extremely late in the day, commission a Rapid Evidence Assessment of the topic. So, almost exactly two years after the consultation, the Ministry of Justice produced, like a rabbit out of a hat, and on the principle of 'fire, take aim, ready', a Rapid Evidence Assessment entitled The Evidence of Harm to Adults Relating to Exposure to Extreme Pornographic Material. This was compiled by three researchers who take the Catherine MacKinnon/Andrea Dworkin line on pornography, so it is hardly surprising that it produced the conclusions which it did, namely that there exist some harmful effects from extreme pornography on some who access it. These included increased risk of developing pro-rape attitudes, beliefs and behaviours, and committing sexual offences. Although this was also true of some pornography which did not meet the extreme pornography threshold, it showed that the effects of extreme pornography were more serious; and that 'men who are predisposed to aggression, or have a history of sexual and other aggression were more susceptible to the influence of extreme pornographic material' (Itzin et al. 2007, iii).

The main problem with the REA is that it simply accepts the definitions of 'extreme pornographic material' laid down by the consultation document, when these are, as we have seen, highly questionable and controversial. It thus entirely begs certain fundamental questions which a more open-minded review would have addressed right from the start. It then goes on to state that 'the majority of research on pornography effects has been experimental studies conducted under laboratory conditions' (ibid.), which is largely true, but what it entirely fails to address is the extent to which findings derived from such experiments have any validity or generalisability outside those laboratory conditions, or indeed outside a particular, US-based model of psychological investigation. It is thus extremely difficult to agree with the REA's conclusion that 'taken together ... the methodologies employed and the findings of studies reported in the REA provide a scientific basis on which to consider the harm effects on victims, including the damage it does to the attitudes, beliefs, fantasies, desires and behaviour of some of those who use it' (ibid., v). In particular, the sense in which an approach with which many psychologists working with 
different methodologies would strongly disagree can be accurately described as 'scientific' is highly questionable. Furthermore, the REA treats as if non-existent what Feona Attwood (2002) has described as 'the paradigm shift in pornography research' away from precisely those behavioural studies on which the REA concentrates to the exclusion of all other approaches.

But the debate in Parliament was never really concerned with 'proof', however methodologically questionable. Thus barely had the Second Reading of the Bill commenced in the Commons on 8 October 2007 than the Secretary of State for Justice and Lord Chancellor, Jack Straw, was denouncing this 'vile material' as 'deeply offensive' (col. 60). But as the Labour MP Ian Mikardo put it in a debate on 3 April 1987 prompted by an ill-fated Tory attempt to tighten up the Obscene Publications Act, the test of gross offensiveness focuses on what might really be called gut reaction. It focuses upon the instant response of shock or disgust to particular pictures, either visual or conjured up in words. The party to the action is described as a reasonable person, but that is merely a code for a tribunal that will decide the issue. A reasonable person will not decide; the magistrate or jury - if there is a jury trial - will decide, and the term 'reasonable person' is really a code name for them. As judges and juries will, of course, always regard themselves as reasonable, they will test the material according to their own personal, subjective and immediate responses. (Col. 1359)

Subjective and moralistic responses were again very much to the fore in the government's attempts to defend the measure in the Lords against a rising tide of concerted Liberal Democrat opposition led by Baroness Miller of Chilthorne Domer. Thus in response to a point which she made on 21 April 2008, Lord Hunt stated that:

The noble Baroness asked whether, having viewed these images at Charing Cross police station a couple of weeks ago, I then felt violent or that I would indulge in some offence. I actually felt very sick, because they were pretty disgusting images, and I frankly find it horrific that they are available and that people can see them. I am sorry, but I do not take this very liberal approach of 'If it does no harm to the people taking part, why should we worry about it?' I do worry about it, and about the access that people have to that kind of disgusting material. I am afraid that is my position ... We are targeting that material not on account of offences which may or 
may not have been committed in the production of the material, but because the material itself, which depicts extreme violence and often appears to be nonconsensual, is to be deplored ... It is appalling that this material is available and we have to do something about it. (Cols 1358-9)

Nor does the Bill's invocation of the 'reasonable person' let it off the subjective hook. The 'reasonable person' (who is quite distinct from the 'average person') is a useful legal fiction which denotes a reasoned and informed outlook on a legal question and is well known in areas such as negligence and contract law. For example, a negligence case might well turn on whether the defendant's conduct was culpable because it fell short of what a reasonable person would do to protect another individual from the foreseeable risks of harm. However, there is a very considerable difference between a jury being asked to decide how a reasonable person would act in such circumstances and how a reasonable person would judge an image - in particular, whether or not they would judge it 'to have been produced solely or principally for the purpose of sexual arousal'. To quote again from lan Mikardo in the 1987 Obscene Publications Act debate: 'There is a difference between reasonableness in respect of a fact, such as negligence, and reasonableness in respect of perception. The Bill is about perception. Nothing is more indeterminate, vague and subjective than a perception' (col. 1355).

But a juror in an 'extreme pornography' case would also be required to determine whether the material in question portrays certain acts in an 'explicit and realistic way' and whether a reasonable person looking at the images of those acts would think that the persons or animals depicted therein were 'real'. Again, this is a vain attempt to put a gloss of objectivity on what are bound to be subjective judgements, but in order to understand how on earth any government could think it necessary - and indeed possible - to legislate in matters pertaining to realism and verisimilitude, we need briefly to explore the genesis of this measure.

In 2003, Jane Longhurst was asphyxiated by Graham Coutts, who visited Internet sites which contained pornography involving violence. He was subsequently found guilty of her murder. As a result, her mother Liz organised a 35,000-strong petition calling for the banning of such sites, in which she was vociferously supported by mediawatch UK (the successor to Mary Whitehouse's lobby group the National Viewers' and Listeners' Association), her MP Martin 
Salter and her daughter's MP David Lepper. Inevitably, the Daily Mail became a cheerleader for the cause, on 30 September 2004 running an article headed 'My sister was murdered by a man obsessed with violent Internet porn. So why won't anyone help me to close these websites down?', which argued that the murder was 'unequally disturbing in that it could have happened only in this high-tech age, committed by someone whose murderous fantasies were fuelled by appalling images freely available on the Internet'. That the court case produced no evidence whatsoever of a direct causal connection, and that at least some of the websites in question (such as Necrobabes) featured relatively tame and clearly staged, consensual scenarios, did not stop Salter and Lepper agitating remorselessly until they bounced this measure onto the statute book.

In other words, the government, terrified as always of being painted as 'soft' on such matters, produced a completely unnecessary, woefully ill thought out and thoroughly oppressive measure in response to a single incident - invariably the worst possible basis for legislation of any kind. Of course, it goes without saying that forcing adults to take part in sexual activity against their will is quite rightly a crime, and that any measure which genuinely helps the police to track down the perpetrators of such acts deserves support. But this most emphatically is not such a measure; it is aimed not at the perpetrators of such acts but at those possessing images of them - and of a very great deal else as well. The measure soon came to be known by its opponents as the Dangerous Images Act - an ironic reference to the Dangerous Dogs Act 1991, a muddled piece of legislation which was passed in a panic following a spate of dog attacks and which resulted in various much-loved and entirely harmless family pets being put down.

The main problem for the government in formulating this measure was that it wanted to avoid the situation in which, as Lord Hunt put it in the Lords on 3 March 2008, the prosecution would have 'to prove that the events being depicted had actually taken place that a person's life had actually been taken or that a life-threatening injury had been inflicted; in short, that a very serious crime had taken place. That would place an insurmountable burden on the prosecution, particularly when so much material is produced abroad' (col. 895). One wonders if Lord Hunt has ever heard of Interpol, but, whatever, absolving the authorities of any need to prove that the images in question do indeed depict 
the commission of actual crimes widens the scope of the legislation to a truly alarming degree.

Thus, for example, a vast range of BDSM material falls fairly and squarely within the ambit of the Act. Such material exists largely for the purposes of sexual arousal, may well be deemed grossly disgusting, offensive or obscene by the uninitiated, and may involve violence which certainly appears to be non-consensual, even though, in fact, it is merely role-playing by entirely consenting participants. As Susan Sontag put it: 'To be involved in sadomasochism is to take part in a sexual theatre, a staging of sexuality. Regulars of sadomasochistic sex are expert costumers and choreographers as well as performers, in a drama that is all the more exciting because it is forbidden to ordinary people' $(1981,103)$. Our legislators may not have read Sontag, but during the period of nearly three years in which the Act was in gestation they received literally hundreds of remarkably well-informed submissions making exactly this point in one way or another - and entirely ignored them. (A series of useful summaries of the main arguments against this measure can be found at http://www.backlashuk.org.uk/oppose.html).

However, the net is cast even wider than this. Thanks to the government's mulish insistence - again, flying smack in the face of a great deal of the expert opinion which it received - on including 'explicit and realistic' portrayals of certain acts within the remit of the legislation, the possession of certain entirely fictional feature films is now set to become a criminal offence. Films classified by the BBFC are exempt from the Act (although not extracts from BBFC-certificated films if these are stored on a disk or tape along with extracts from other films, whether or not BBFC-certificated), but there is a huge range of unclassified material available from abroad (and indeed from the United Kingdom) on DVD at the click of a mouse (indeed, from the government's point of view, that is precisely the problem). Particularly at risk, of course, are films which include both real sex and simulated violence. Examples which immediately spring to mind are Joe d'Amato's Emanuelle in America (1977) and Emanuelle Around the World (1977), Oswaldo de Oliveira's Bare Behind Bars (1980), many of the films of Jess Franco, and indeed whole swathes of European horror, crime and sex films which took advantage of relaxed censorship regimes in countries such as Italy and Spain from the late 1970s onwards. The fact that DVDs of these movies are easily available not simply from specialist dealers but from Amazon.com, hardly a sink of depravity, is the clearest possible 
indication that the standards of acceptability which the British government is attempting to impose on its subjects are simply out of kilter with those in most of the rest of the democratic world.

Of course, it might be argued that as long as the police interpret this legislation sensibly, it will not capture the extremely wide range of material which I have suggested. However, the record of the police in the matter of allegedly indecent images of children hardly gives cause for optimism in this respect, as on various occasions they have pursued parents who had taken photos of their children in the bath, and have also attempted to pressurise galleries to withdraw photos of children by Robert Mapplethorpe, Nan Goldin and Tierney Gieron, amongst others. Furthermore, the record of police (ab)use of the Video Recordings Act 1984 to invade the homes of private video collectors, seize their collections, and drag them through the courts and their local media is a truly appalling one. (For details of such activity, see Kerekes and Slater 2000 and Petley 2000).

Entirely unsurprisingly, then, the police were among the very few to respond positively to the consultation on this matter. A worryingly large number of the police responses were marked by bitter resentment that those arrested and charged under the Obscene Publications Act had dared to avail themselves of the defences available under it, demands for more resources so that the proposed new measure could be enforced effectively, and complaints that the proposed offences were too narrow and the proposed sentences too short. In the end, it's extremely hard to avoid the conclusion that many of the respondents regard those whom they are policing as, to coin a constabulary phrase, 'swirling around in a human cesspit of their own making'. (Responses to the consultation were initially available on the Home Office website. However, they are no longer there).

The best example of this sort of attitude came not from the responses themselves but from an article by the above-mentioned Detective Inspector lan Winton of the Nottinghamshire police in the Nottingham Post, 31 August 2006, in which he threatened: 'We will not hesitate in using this new legislation. Those convicted of this new offence will have to sign the sex offenders' register which will affect not just their relationship with friends and family but also their careers. It will make many users of extreme pornography think again'. Meanwhile Detective Inspector Colin Gibson of the Economic Crime Unit, Durham 
Constabulary was amongst the many arguing that the proposed measures did not go far enough. In his view:

Whilst it is accepted that it is the intention to restrict any new offence to pornographic material many would argue that this is a conservative list and leaves room for development. Not all abhorrent images are produced for sexual gratification. Some are quite clearly just obscene and offensive and without a sexual connutation [sic] yet simple possession would still fall outside of current and proposed legislation.

Detective Sergeant Keith Wharton of the West Midlands Police wanted adding to the list 'the eating of faeces or urine', whilst Detective Inspector Winton stated that:

In our opinion acts of coprophilia (excrement, urination) within pornograph [sic] are examples of the total degradation of the person subject of such acts. It is our view that such acts are enjoyed by sadists. Likewise acts of belonephilia (needles fetish) agonophilia (pseudo rape) and other forms of extreme violence are also enjoyed by sadist [sic] and those persons with sadistic tendencies. Such tendencies would skew the mindset of the viewer of such material to believe that this is the norm. As such we feel it should not be tolerated.

Most worrying of all, however, was the response from John Francis, the General Secretary of the Police Federation of England and Wales, who argued that:

The circumstances in which the material is found is not, at the present time, considered when sentencing takes place, as only the image charged can be so considered. This applies when considering the sexual nature of an image. For example, so called 'snuff movies' whereby persons are actually killed on screen are currently not considered for a sexual motive. The circumstances in which the images are found should be considered. There is evidence of these movies being found with a great deal of pornography, which in itself is not illegal to possess. This also applies to mutilation images, scenes of crime images of murder victims, beheadings, etc. The question to be asked is why anyone would want these images in the first place. It is the circumstances in which they are found that implies a sexual motive. However, as 
legislation stands at present no account can be taken of them, as it is not illegal to possess these images.

Thus, it is suggested in all seriousness that that if someone possess images of death and violence, and if they also possess pornographic images, then they are in possession of the former for reasons of sexual gratification.

Such responses, along with police enforcement of the Protection of Children Act and the Video Recordings Act, suggest all too strongly that the police simply cannot be trusted to act reasonably or intelligently in matters pertaining to pornography and obscenity. The fact that they have been handed yet another excuse to batter down people's doors in dawn raids, seize their computers, videos, DVDs, books and magazines, and ensure that their names are plastered across the local and, in the cases of the famous, national media, quite simply beggars belief. One's fears in this respect are only heightened by Lord Hunt's revelation in the Lords on 30 April that 2008 that the police see this offence as 'a further means to take illegal material out of circulation and an additional tool to deal with individuals whose behaviour may be causing concern' (col. 271). In other words, having failed under existing laws successfully to prosecute people whom, for whatever reason, they want to see behind bars, the police are to have this task greatly facilitated by catch-all legislation of the most illconceived kind.

Back in 1999, writing when the threats to the freedom of the Internet and its users were less developed, or at least less overt, than they are today, Adam Newey proposed a liberal rubric for censorship in the Internet age:

The Internet challenges us to revise our notion of censorship itself, by giving the user and reader the power and responsibility to decide what he or she wants to access and what to block. Broadly speaking, this is in line with a general policy trend in the industrialised democracies: as the welfare and regulatory provisions of the state are rolled back, so the responsibility for censorship devolves to the level of the local user, the family or service provider, and away from any constituted state authority. $(1999,15)$

However, in the United Kingdom at least, the individual is most clearly not going to be allowed exercise this responsibility free from state surveillance, as an agent of the state is 
effectively going to be installed in their head in order to make them wonder if the next click of the mouse will involve them in committing an illegal act and result in their going to prison. The model here, as noted earlier, is that of Bentham's Panopticon. It is also that of Orwell's 1984, whose inhabitants never knew when they were being observed through the ubiquitous telescreens:

How often, or on what system, the Thought Police plugged in on any individual wire was guesswork. It was even conceivable that they watched everybody all the time. But at any rate they could plug in your wire whenever they wanted to. You had to live - did live, from habit that became instinct - in the assumption that every sound you made was overheard, and, except in darkness, every movement scrutinised. $(1954,6)$

Significantly, in Privacy International's 2007 global survey of privacy, the United Kingdom joins forces with the United States, Thailand, Taiwan, Singapore, China, Russia and Malaysia as an 'endemic surveillance society' (2007), whilst the Home Affairs Select Committee has argued that 'the potential for surveillance of citizens in public spaces and private communications has increased to the extent that ours could be described as a surveillance society unless trust in the Government's intentions in relation to data and data sharing is preserved' $(2008,99)$.

This paper has attempted to analyse the anti-pornography clauses of the Criminal Justice Act 2008 as a response, albeit a highly problematic one, to the difficulties posed by the Internet to traditional, nationally-based forms of media regulation. It has suggested that the government's enforced shift from attempting to regulate media content to attempting to regulate the behaviour of media users moves the debate away from the censorship of media texts and into the realms of surveillance and 'panopticism'. However, it might be useful to conclude by placing this measure also within its broader political context, and in particular by relating it to New Labour's much remarked-upon attempts to micromanage people's lives and to intrude the law into spheres generally marked out as private in a liberal polity. Indeed, one of the most striking features of New Labour is that whilst 'deregulating' the economy to a degree which even some Tories find worrying, it has been highly judgemental, interventionist and indeed dirigiste in a whole range of social matters. (For an extended discussion of this topic, see Petley 2007). As Stephen Driver and Luke Martell put 
it in a remarkably prescient study of the early days of New Labour in power: 'There is a reliance on legislative solutions to what are presented as ethical threats. Whatever the problem - bad behaviour in schools, noisy neighbours, children on the streets in the late evening - New Labour seems poised to reach for the legal pen' $(1998,119)$. Unwilling to legislate for corporate responsibility, New Labour, in thrall to a particular North American version of 'communitarianism' exemplified by the work of Amitai Etzioni, has been all too happy to pass numerous laws regulating individual behaviour and responsibilities, and to make public moral judgements on individual lifestyles. In many ways, this can be seen as Labour's final abandonment of the Wolfenden strategy, which governed much liberal thinking in the 1960s and 1970s and which relied on a clear distinction between private behaviour (which was regarded as a domain of choice between consenting adults) and public behaviour (which was the legitimate realm of regulation and control). As Will Hutton has observed:

As evidence of social fragmentation mounts, there is an increasingly shrill cry to remoralise society - in which morality is regarded as the prohibition of individual actions backed by repressive legislation. Economic and social reforms, which might address the roots of these problems, are seen as a return to what has failed; instead the future is one of moral individuals, caned at school, smacked at home and wary of steep punishment in prison fixed by automatic sentencing, who keep their families together and so stand as bulwarks against social implosion ... Nor does the talk of admonition and prohibition stop there. The climate which produces constraints and bans does not begin and end with school expulsions and longer sentences for offenders of all ages; it extends seamlessly into the censorship of books, films and theatres. $(2007,8)$

That this was actually written about the last Conservative government, on the eve of the election of New Labour, but is even more applicable to the present government, is extremely revealing of the United Kingdom's drift towards what has been called the postsocial democratic state. The criminalisation of even the mere possession of the 'wrong' kinds of porn by the Criminal Justice and Immigration Act 2008 is but one symptom of this trend, and in this respect it is worth noting that the Act also brings into being yet another punitive measure designed to shortcut due legal processes (the ASBO-like Violent Offender 
Order), creates a sinister-sounding 'special immigration status' allowing restrictive conditions to be placed on the families of non-nationals who have been convicted of offences in the United Kingdom, gives government ministers powers over the sentencing of individual offenders in individual cases, reduces the powers of the Court of Appeal to quash a criminal conviction in certain circumstances, and limits the amount of compensation to be paid to victims of miscarriages of justice. In other words, the anti-porn proposals are in good company.

\section{References}

Akdeniz, Yaman, Walker Clive and Wall David 2000. The Internet, Law and Society. Harlow, UK: Longman.

Attwood, Feona 2002. 'Reading Porn: The Paradigm Shift in Pornography Research.' Sexualities 5: 91-105.

Castells, Manuel 2001. The Internet Galaxy: Reflections on the Internet, Business and Society. Oxford, UK: Oxford University Press.

Child Exploitation and Online Protection Centre 2003. UK police uncover global online paedophile network, http://www.ceop.gov.uk/mediacentre/pressreleases/2008/ceop 18082008.asp (2 April 2009).

Craig, Thomas and Julian Petley 2001. 'Invasion of the Internet Abusers: Marketing Fears about the Information Superhighway.' Pp. 186-201 in III Effects: The Media/Violence Debate, 2nd ed. edited by Barker Martin and Petley Julian. London, UK: Routledge.

Driver, Stephen and Martell Luke 1998. New Labour: Politics After Thatcherism, Cambridge, UK: Polity.

Foucault, Michel 1977. Discipline and Punish: the Birth of the Prison, London, UK: Allen Lane.

Goldsmith, Jack and Wu Tim 2008. Who Controls the Internet? Illusions of a Borderless World. Oxford, UK: Oxford University Press. 
Home Office 2005a. Consultation: On the Possession of Extreme Pornographic Material. London, UK: Home Office Communication Directorate. This can also be viewed at http://www.homeoffice.gov.uk/documents/cons-extreme-porn-3008051/.

Home Office 2005b. Crackdown on violent pornography,

http://press.homeoffice.gov.uk/press-releases/Crackdown On-Violent Pornography (2 April 2009).

Home Office 2006. New offence to crack down on violent and obscene pornography, http://press.homeoffice.gov.uk/press-releases/crack-down-on-pornography (2 April 2009). House of Commons Home Affairs Committee 2008. A Surveillance Society? London, UK: TSO. Hutton, Will 2007. The State to Come. London, UK: Vintage.

Itzin, Catherine, Ann Taket and Liz Kelly 2007. The Evidence of Harm to Adults Relating to Exposure to Extreme Pornographic Material: a Rapid Evidence Assessment (REA). London, UK: Ministry of Justice.

Joint Committee on Human Rights 2008. Legislative Scrutiny: Criminal Justice and Immigration Bill. London, UK: The Stationery Office.

Kerekes, David and David Slater 2000. See No Evil: Banned Films and Video Controversy. Manchester, UK: Headpress.

Lyon, David 2006. Theorizing Surveillance. Uffculme, UK: Willan Publishing.

Lyon, David 2007. Surveillance Studies: an Overview. Cambridge, UK: Polity. Newey, Adam 1999. 'Freedom of Expression: Censorship in Private Hands.' Pp. 13-43 in Liberating Cyberspace: Civil Liberties, Human Rights and the Internet, edited by Liberty. London, UK: Pluto.

Orwell, George 1954. 1984. Harmondsworth, UK: Penguin.

Petley, Julian 2000. "'Snuffed Out": Nightmares in a Trading Standards Officer's Brain.' Pp. 203-19 in Unruly Pleasures: the Cult Film and its Critics, edited by Mendik Xavier and Harper Graeme. Guildford, UK: FAB Press.

Petley, Julian 2007. 'New Labour: Old Morality.' Index on Censorship 36: 132-40. 
Privacy International 2007. The 2007 international privacy ranking, http://www.privacyinternational.org/article.shtml?cmd[347]=x-347-559597 (2 April 2009). Rheingold, Howard 1993. The Virtual Community: Homesteading on the Electronic Frontier. Cambridge, MA: MIT Press.

Robertson, Geoffrey and Nicol Andrew 2008. Media Law, 5th edn. London, UK: Penguin. Sontag, Susan 1981. Under the Sign of Saturn. New York, NY: Vintage Books.

Villeneuve, Nart 2007. 'Evasion Tactics'. Index on Censorship 36: 71-85. 